\title{
Diversity and Inclusion Initiatives for Female Employees in the Workplace- A Case Study
}

Amirdavarshini Muralithar* and Vijaya $\mathrm{R}^{\dagger}$

\begin{abstract}
XYZ Ltd. an organisation in the IT industry is facing high level of female attrition. The organisation decides to counter this by introducing a number of policies that are aimed at enhancing the work life balance of the female staff in the organisation. Three policies were introduced namely, one, extending the maternity leave by two months (without pay), two, work from home, and three, introducing a crèche facility. Of this, the policy on crèche facility is still in its trial period. This case speaks about the process of reviewing the policy.
\end{abstract}

Keywords: Attrition, Work Life Balance, Maternity Leave, Flexihours, Crèche Facilities

\section{Introduction}

XYZ Ltd. is an IT services provider with over 9000 employees working out of 23 countries around the world. The company provides very focused IT services to ensure it can grow its expertise in those areas. Established in the early 1980's, the company grew exponentially through the 1990's and 2000's. The organisation soon made its global presence known and is still expanding.

${ }^{*}$ Christ University, Bengaluru, India;

amirdavarshini.muralithar@psy.christuniversity.in

† Christ University, Bengaluru, India; vijaya.r@christuniversity.in 


\section{The Case:}

Sahana Shankar, the CPO of XYZ Ltd., an IT consulting company, rushed from the parking to her office, to find Rajiv Mahtolia, the Corporate Head HR and Alena Joseph, the Line HR waiting for her in her office. They both wished her a good morning as soon as she entered.

"Good morning" she said as she motioned for them to take their seats. "Sorry I'm late; the traffic was terrible", she said as she settled down, "have you been waiting for long?" Rajiv and Alena were part of the team that designed the new policies which had been implemented almost six months ago.

The Mission of the organisation was centred around having a diverse and equal workforce. Contrary to this, the organisation recently had found that the sex ratio was highly skewed towards male employees. This however is not a new trend in the IT industry, as seen by several large-scale surveys conducted using the diversity reports published by leading companies annually. For instance, such an analysis in the year 2015 saw that the average percentage of women working in the tech industry hovered around 30 (Cheng, 2015). A report by McKinsey Global Institute states that if participation of women in the workforce in India is increased to $41 \%$ by 2025 , an estimated value of 46 Lakh Crore can be added to the GDP. This and similar statistics now act as immense motivators for large organisations to shift their focus and commitment towards creating a more equal playing field for both genders.

In service of this goal XYZ Ltd., conducted several research surveys to identify and understand why the data was so skewed, and found two things. One, the numbers in recruitment itself was skewed towards males, and two, female attrition was found to be higher than the average male attrition.

As the next step, extensive interviews were conducted with the management, female staff and prospective candidates who opted out of recruitment as well as previous employees, and these problems were themed and listed. The problems documented were then compared with the reasons stated by ex-employees in their exit interviews. Marriage, pregnancy and child care were found to be most recurring. As stated by Naila (2012), most women quit 
their jobs either after marriage or due to social pressures arising out of irregular working hours which are typical to this industry. Similar to this research finding, the female interviewees often showed concern towards balancing their duties and working so far away from home. Female attrition by far is not a new concept, especially in the IT sector.

A more recent study conducted by Kumar and Melba (2015) on a sample size of 523 found that IT companies in Techno park, Thiruvananthapuram, needed to implement retention strategies focusing on compensation policies, changes in work requirements and improving the working conditions. Taking cue from such findings, and with the backing of sufficient evidence from these interviews, the senior management decided to target this issue by introducing policies to help enhance the work life balance of female employees.

One such policy was to increase the maternity leave by 2 months. This meant that the women who were earlier provided with four months of paid leave post-delivery, could avail two more months of leave, without pay. Post this, in case there were any health complications or medical exigencies, they were also eligible to avail the 'work from home' policy, i.e. flexi-hours. However, to avoid abuse, this could only be availed with a doctor's certificate, stating that the female employee cannot come to work for at least fifteen days. This policy would allow the employee to work from home, till she recovers.

A third policy that the organisation implemented was that of providing an in-house crèche facility. This facility had been implemented as a trial, the review for which was to be held the next week.

"No, we just arrived." Rajiv said as she switched on his laptop. Rajiv and Alena had worked with Sahana to develop the policy on providing the female employees with a crèche facility. They had been monitoring how many employees availed this provision, and were working on collecting feedback. They had prepared a presentation and were here to discuss the data collected with Sahana before the upcoming review. "Okay guys, let's get started?" Sahana asked. 


\section{Worrying facts}

As Rajiv went on with his presentation, Sahana was filled with mixed emotions. "So what you are saying is, that every single female employee is aware of this new policy, but only a few are using it." She was happy that the awareness programmes conducted for the crèche service had been quite successful. But at the same time, she now knew that very few of the employees had started to use it. Eight months ago, it had been decided that a crèche facility will be introduced in the company, and this team had been formed to conduct a benchmarking survey, as well as formulate and implement a policy for the same. It had been almost six months since the policy had been put in place, but the response to it was quite disappointing. "What does the feedback say, why are only a few employees using these services?" she inquired.

To this, Alena responded, "Ma'am, we found that there were two major problems that the women faced" she pointed to the data on the laptop, and continued, "The first was a lack of trust. They feel that since the crèche facility is outsourced it is not as safe. They are uncomfortable with strangers taking care of their children." Since the facility was newly introduced in the organization and was still in its early stages, an agency was hired for the in-house day-care. This seemed to make the female staff unsure of the security aspect. "Another feedback which we have got is from the male staff." Alena Continued.

"The male staff?" Sahana asked, surprised. Sahana had been reading about the rise of paternity leaves as a means of engaging male employees in order to reduce employee turnover (Florentine 2014), however she had not expected such a reaction from the male staff. This was a policy specifically designed for the female staff!

"Yes ma'am. We noticed during the promotional activities conducted for the policy that many of the male staff members were quite interested in the crèche facilities, but were disappointed to know that it was provided only for the female staff." Alena responded.

“That is wonderful news, it's good to see more people wanting to use the facility. We can bring this up next week in the meeting. I 
must say, I am very surprised that we have received such a positive response from the male staff" said Sahana.

Alena continued, "Also, we got one more feedback about Anita." Anita was one of the caretakers working in the crèche. Many of the employees had complained about her to the HR, for being very strict with the children, which Sahana already knew about her.

\section{The resolution}

The reviewing board went through the various concerns of the female staff at the organisation. The first concern of safety was brought to the attention of the agency providing the day-care facility. The organisation and the agency worked together to set a system that allowed the parents access to the CCTV cameras in the crèche. This served as a way for the parents to check in on their children, and be sure that the caretakers were also doing their jobs properly.

The second concern, about a particular employee, was also addressed immediately. All the employees who lodged a complaint were allowed to voice the problems they faced with her. These problems were brought to the attention of the agency, who immediately terminated her service.

The policy for the crèche facility was also expanded to cater to the male staff, i.e. the male staff could now bring their children to the day-care. This was done with the aim of promoting the facilities available. Another review was scheduled to be conducted in the following six months. Similar to the first six months, the HR departments were asked to take continuous feedback to ensure that any immediate concerns are not left unnoticed.

\section{Conclusion}

In today's workplace scenario, it is highly important for an organisation to not only accommodate, but also include and engage a highly diverse and skilled workforce. The increasing diversity in today's workforce is being viewed more as an opportunity, as it allows an organisation to retain premium talent. After having realised this, XYZ Ltd. has started to take steps towards retaining its female staff, primarily by improving their work life balance. 
However, an important and larger lesson learnt by Sahana and her team was that no policy can strictly be focused on one target population without considering the impact on the wider population. In this case it referred to the crèche facility, which received a very positive response from the male staff. Any policy that is installed needs to be viewed holistically to not only ensure that the intended effect is felt, but also that no unintended consequences are felt.

\section{Questions}

1. What contemporary measures do you think can encourage diversity in organisations today?

2. What other measures can be created to cater to needs of both the male and female employees?

3. What other causes can be there for high female attrition?

4. Do you think the measures taken were more reactive than proactive?

Disclaimer: All the names mentioned in this case study have been changed to maintain confidentiality. Resemblance to any person living, or deceased is purely coincidental.

\section{References}

Cheng, R. (2015, May 6). Women in tech - the numbers dont add up. Retrieved from c/Net: https://www.cnet.com/news/women-in-tech-thenumbers-dont-add-up/

Florentine, S. (2014, October 29). Lack of Parental Leave Drives Employee Turnover. Retrieved from CIO: http://www.cio.com/ article/ 2840574/staff-management/lack-of-parental-leave-drives-employeeturnover.html

How companies are engaging women on maternity leaves? (2016, October 26). Retrieved from People Matters: https:// www.peoplematters.in / article/diversity/how-companies-are-engaging-women-on-maternity -leaves-14369?utm_source=peoplematters\&utm_medium = interstitial \&utm_campaign=learnings-of-the-day

Kumar, R., \& Melba, A. (2015). A study on women employee attrition in IT industry with special reference to technopark, Thiruvananthapuram. International Journal of Management Research $\mathcal{E}$ Review, 528-534. 
Naila, I. (2012). Analysing Causes of Attrition Rate and Giving the Solution Through Maslow's Hierarchy of Need in BPO Industry. Rajeev Ganfhi College Research Journal, 1-14. 